\title{
First records of the chewing louse Mulcticola hypoleucus (Denny, 1842) on the Eurasian nightjar Caprimulgus europaeus Linnaeus, 1758 in the Benelux
}

\author{
Ruben Evens $^{1, *}$, Natalie Beenaerts ${ }^{2}$, Nele Witters ${ }^{3}$ \& Tom Artois ${ }^{1}$ \\ ${ }^{1}$ Hasselt University, Centre for Environmental Sciences, Research Group Zoology: Biodiversity and \\ Toxicology, Campus Diepenbeek. Agoralaan, Gebouw D, 3590 Diepenbeek, Belgium. \\ ${ }^{2}$ Hasselt University, Centre for Environmental Sciences, Research Group: Environmental Biology, \\ Campus Diepenbeek. Agoralaan, Gebouw D, 3590 Diepenbeek, Belgium. \\ ${ }^{3}$ Hasselt University, Centre for Environmental Sciences, Research Group: Environmental Economics, \\ Campus Diepenbeek. Agoralaan, Gebouw D, 3590 Diepenbeek, Belgium. \\ *Corresponding author: ruben.evens@uhasselt.be
}

KEYWORDS. Parasite, Caprimulgus, nightjar, metapopulation, louse.

Evens R., Beenaerts N., Witters N. \& Artois T. (2018). First records of the chewing louse Mulcticola hypoleucus (Denny, 1842) on the Eurasian nightjar Caprimulgus europaeus Linnaeus, 1758 in the Benelux. Belgian Journal of Zoology 148 (1): 25-29. https://doi.org/10.26496/bjz.2018.17

Obligate host-parasite interactions, such as those between birds and chewing lice Mallophaga (Nitsch, 1818), are considered ideal model systems to study the bidirectional impact of both host and parasite on ecological and evolutionary processes [1-4]. Chewing lice, for example, can influence the host's fitness by reducing mating success [5] and can cause extensive feather damage, which affects flight capability or thermoregulation [6], whereas various host characteristics are known to serve as selective pressures that affect parasite evolution [7, 8].

Chewing lice form a paraphyletic group with respect to sucking lice Anoplura (Leach, 1815) [9] in the insect order Phthiraptera (Haeckel, 1896). On birds, species of two suborders of chewing lice have been described: Amblycera Kellogg, 1896 and Ischnocera Kellogg, 1896. Most species are host-specific ectoparasites that complete their entire life cycle [i.e., egg phase (4-10 days), three nymph stages (3-12 days/stage) and adult life (one month)] on the body of a single host. Here, they feed on skin debris, blood or feather keratin [10]. In order to transfer to other hosts chewing lice mainly rely on vertical (adult to chick) and horizontal transmission (between roosting or copulating individuals) [11]. Other than bodyto-body contact, some species of Ischnocera are also capable of moving between hosts by phoresy on hipposboscid flies [12] or via dust baths and shared nest cavities [13].

Species of Mulcticola are small elongated feather lice that are morphologically and behaviourally adapted to hide between the barbs of wing and tail feathers in order to avoid host preening [9]. Within Philopteridae (Burmeister, 1838 sensu lato Ischnocera: Philopteridae) the genus Mulcticola (Clay \& Meinertzagen, 1938) contains 18 described species, which are usually confined to a single species of nightjar or nighthawk (Aves: Caprimulgiformes) [14], with the exception of M. balati Tendeiro, 1962, found on three species of nightjar and M. bacurau (Valim \& Kuabara, 2015), and also found on the 
Table 1

Overview of the number of Mulcticola hypoleucus Denny, 1842 found on each examined Eurasian nightjar. Nymph I - II -III = nymph stage; $\mathrm{M}=$ Male; $\mathrm{F}=$ Female.

\begin{tabular}{ccccccc}
\hline ID & Year & Nymph I & Nymph II & Nymph II & Adult M & Adult F \\
\hline Chick 1 & 2013 & - & - & - & - & 2 \\
Chick 2 & 2015 & & - & - & - & - \\
Chick 3 & 2016 & - & - & - & 1 & 7 \\
Adult 1 & 2013 & - & - & - & - & - \\
Adult 2 & 2016 & - & - & - & - & 1 \\
Adult 3 & 2016 & - & - & & & \\
\hline
\end{tabular}

ovenbird Furnarius figulus (Lichtenstein, MHK, 1823)[13]. Little is known about the biogeographic distribution of species of Mulcticola and estimates of parasite distribution are generally based on the hosts' range. Mulcticola hypoleucus (Denny, 1842) (syn. Nirmus hypoleucus Denny, 1842) (Fig. 1) is exclusively found on the Eurasian nightjar (Caprimulgus europaeus Linnaeus 1758) and no other species of Mulcticola has been found on the Eurasian nightjar either (hereafter referred to as nightjar). M. hypoleucus has been found on nightjars across the Palearctic region, more specifically in Bulgaria, Czech Republic, Finland, Germany, Hungary, Poland, Romania, Spain, Tajikistan, Turkey and the United Kingdom. This species was also added to the "Chewing lice of Belgium" in 2004 [16]. However, inclusion on the Belgian list was solely based on the presence of its host as a breeding species in Belgium (pers. comm. R.A. Hellenthal). In order to add details on the distribution of M. hypoleucus, we report here on the first observations of this ectoparasite in the Benelux.

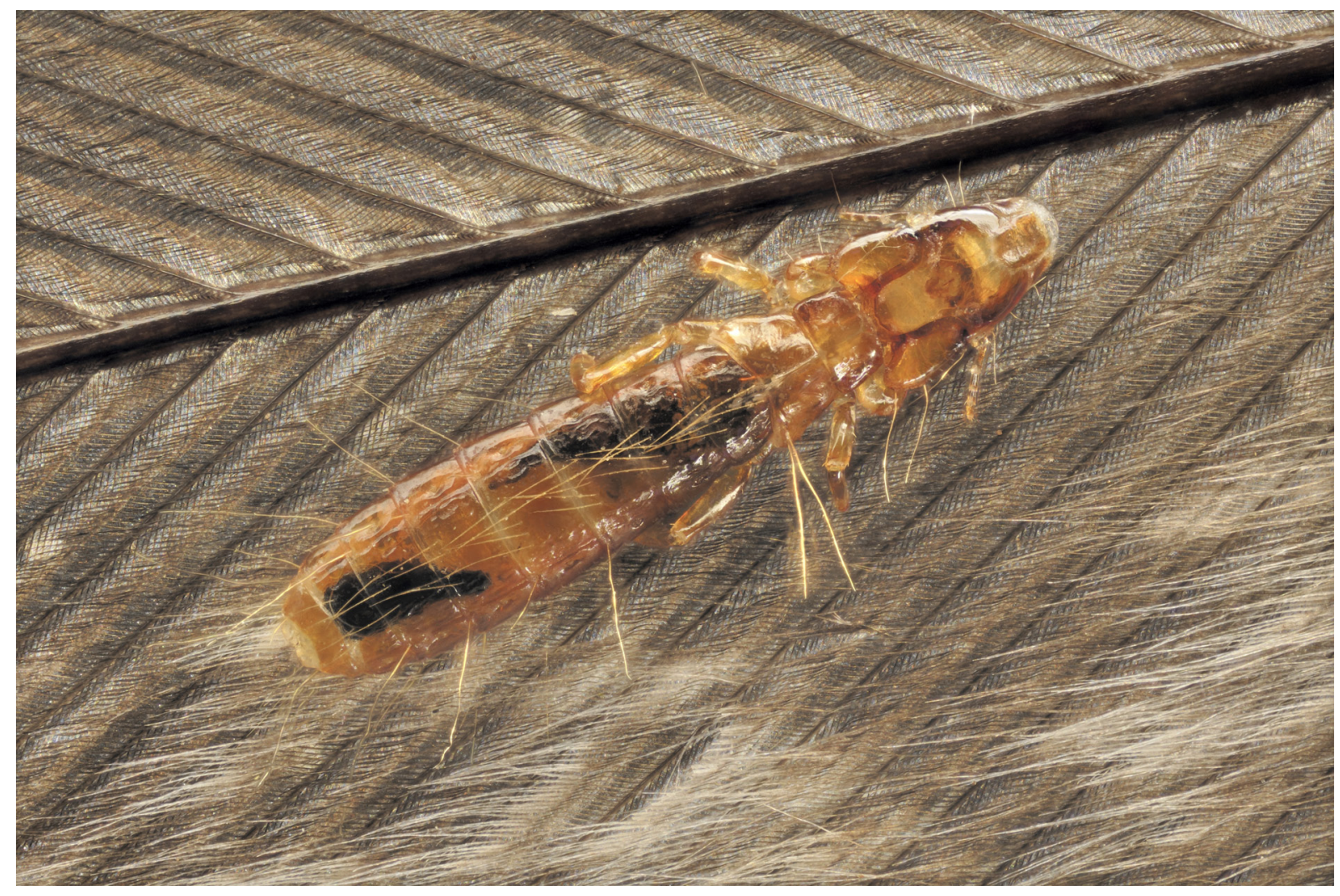

Fig. 1 - Mulcticola hypoleucus (Denny, 1842) (syn. Nirmus hypoleucus Denny, 1842) found on the feathers of a Eurasian nightjar (Caprimulgus europaeus Linnaeus 1758) in Belgium. 
In the context of a long-term study on population dynamics and space use of nightjars, in the province of Limburg (Belgium), 528 nightjars were captured and 97 recaptured between 2011 and 2016. All nightjars were fitted with a metal ring from the Royal Belgian Institute for Natural Science (RBINS) and wings were visually examined for the presence of ectoparasites. Three unrelated chicks (3-7 days old) were found dead during the course of our study and were individually packed and stored at $-20^{\circ} \mathrm{C}$ for later examination.

On each of three living adult nightjars, we found one specimen of Mulcticola hypoleucus, altogether one male and two adult females (Table 1). In total, we collected two adult males, nine adult females and three nymphs of Mulcticola hypoleucus on the dead chicks (Table 1).

Furthermore, we found ten specimens of Ornithomyia avicularia (Linnaeus, 1758) (Diptera: Hippoboscidae) on other, unrelated living nightjars (one specimen on each bird) and two deuteronymphs of the mite Poecilochirus necrophori (Vitzthum, 1930) (Acari: Mesostigmata: Parasitidae) on one dead chick (Table 1 , Chick $n^{\circ} 1$ ). Ornithomyia avicularia is a species of louse fly that can infest a wide range of bird species [17]. Poecilochirus necrophori mainly parasitize fly maggots and use burying beetles to be transported between corpses of dead animals. Therefore, these two deuteronymphs, found on the corpse of a dead chick were probably transported there by burying beetles (Nicrophorus sp.) [18].

Visual examination of wing feathers appeared to be an inefficient method to find lice on adult nightjars. These mobile, brown-bodied parasites can hide under the feathers and are difficult to distinguish from the brown/grey nightjar feathers. Additionally, earlier studies have shown that it is very inefficient to visually count lice on the wings of lightly-parasitized birds [9]. Therefore, we expect that our observations are underestimates of the true ectoparasite prevalence and intensities on nightjars. It would have been more appropriate to use dust-ruffling or fumigation chambers in order to determine parasite abundance on living nightjars. In both those methods, birds are contained in small bags/containers and parasites are killed and collected therein using pyrethrin dust [19] or ethyl acetate fumes [20]. However, because of time restrictions, we did not apply either of these two methods.

We examined the corpses of the dead chicks more thoroughly compared to the bodies of the living, adult birds. This could explain the seemingly different ectoparasite prevalence between chicks and adults in our study (Table 1). Little is known about population dynamics of species of Mulcticola on nightjars and nighthawks. A recent study of Galloway \& Lamb [21], however, suggests that parasite intensity on adult nighthawks Chordeiles minor (Foster, JR, 1771) increases in spring. This would ensure females of the chewing louse Mulcticola macrocephalus (Kellogg, 1896) were transferred to chicks during the incubation period. In addition, ectoparasite prevalence and intensities can also differ between species and are often influenced by host characteristics, such as body size [22], bill shape and size - used for preening - [22], age related behaviour [23], sociality [24], chick development (i.e., feather growth) and nesting behaviour [25]. For example, in contrast to our findings, ectoparasite intensity on young chicks of the European bee-eater Merops Apiaster (Linnaeus, 1758) was found to be lower as compared with adults [11]. We also found nine adults of M. hypoleucus on one of the chicks. These ectoparasites probably moved as adults via vertical transmission from the adult bird to the chick. In contrast, vertical transmission of chewing lice in swifts Apus apus (Linnaeus, 1758) mainly occurs when nymphs move from the adult bird to the chicks [26] and subsequently complete their entire life on the body of this new host [12].

Most species of Mulcticola are confined to one species of nightjar or nighthawk. In the case of M. hypoleucus, observations have been made across the distribution of the Eurasian nightjar's breeding range [14]. It is, however, unclear whether co-speciation occurred between Mulcticola and Caprimulgiformes because little is known about historic events of host switching or coalescence times [11]. Careful investigation will be required to understand the complex host-parasite association between Mulcticola and Caprimulgiformes [27]. Evidently, more work is needed to improve our understanding of the diversity of chewing lice that are associated with Caprimulgiformes across their global range. 


\section{Acknowledgements}

RE is funded by a BOF-mandate (BSFFCMKDK) at Hasselt University. NW is funded as a postdoctoral researcher by FWO Flanders. Research equipment was funded by the Agency for Nature and Forest (ANB) (Belgium). Permissions were granted by the ANB and Royal Belgian Institute of Natural Sciences (Belgium). We thank Herman Cremers for identifying the parasites. We also thank Eddy Ulenaers, Albert Geuens, Karen Vanmarcke and Fien Evens for their support.

\section{References}

1. Hughes J., Kennedy M., Johnson K.P., Palma R.L. \& Page R.D.M. (2007). Multiple cophylogenetic analyses reveal frequent cospeciation between Pelecaniform birds and Pectinopygus lice. Systematic Biology 56: 232-251. https://doi.org/10.1080/10635150701311370

2. Johnson K.P., ShreVE S.M. \& SMith V.S. (2012). Repeated adaptive divergence of microhabitat specialization in avian feather lice. BMC Biology 10: 52. https://doi.org/10.1186/1741-7007-10-52

3. Harper S.E., Spradling T.A., Demastes J.W. \& Calhoun C.S. (2015). Host behaviour drives parasite genetics at multiple geographic scales: population genetics of the chewing louse, Thomomydoecus minor. Molecular Ecology 24: 4129-4144. https://doi.org/10.1111/mec.13306

4. LeavitT D.H., Starrett J., Westphal M.F. \& Hedin M. (2015). Multilocus sequence data reveal dozens of putative cryptic species in a radiation of endemic Californian mygalomorph spiders (Araneae, Mygalomorphae, Nemesiidae). Molecular Phylogenetics and Evolution 91: 56-67. https://doi.org/10.1016/j.ympev.2015.05.016

5. Moreno-Rueda G. \& HoI H. (2012). Female house sparrows prefer big males with a large white wing bar and fewer feather holes caused by chewing lice. Behavioral Ecology 23: 271-277. https://doi.org/10.1093/beheco/arr182

6. Boоth D.T., Clayton D.H. \& Block B.A. (1993). Experimental demonstration of the energetic cost of parasitism in free-ranging hosts. Proceedings of the Royal Society B, Biological Sciences 253: 125-129. https://doi.org/10.1098/rspb.1993.0091

7. Clayton D.H., Bush S.E. \& Johnson K.P. (2016). Coevolution of Life on Hosts: Integrating Ecology and History. University of Chicago Press, 294 pp.

https://doi.org/10.7208/chicago/9780226302300.001.0001

8. Clayton D.H. \& Moore J. (eds) (1997). Host-Parasite Evolution: General Principles and Avian Models. Oxford University Press, Oxford, 473 pp. https://doi.org/10.1016/S0169-4758(97)01174-5

9. Johnson K.P. \& Clayton D.H. (2003). The biology, ecology, and evolution of chewing lice. In: Price R.D., Hellenthal R.A., Palma R.L., Johnson K.P. \& Clayton D.H. (eds) The Chewing Lice: World Checklist and Biological Overview: $\mathrm{x}+501$ pp. Illinois Natural History Survey Special Publication 24.

10. Price R.D., Hellenthal R.A., Palma R.L., Johnson K.P. \& Clayton D.H. (2003). The Chewing Lice: World Checklist and Biological Overview. Illinois Natural History Survey Special Publication, $\mathrm{x}+501 \mathrm{pp}$.

11. Darolova A., Hoi H., Kristofik J. \& Hoi C. (2001). Horizontal and vertical ectoparasite transmission of three species of Malophaga, and individual variation in European bee-eaters (Merops apiaster). Journal of Parasitology 87 (2): 256-262. https://doi.org/10.1645/0022-3395(2001)087[0256:HAVETO]2.0.CO;2

12. Rozsa L., REKASI J. \& ReICZIGel J. (1996). Relationship of host coloniality to the population ecology of avian lice (Insecta: Phthiraptera). Journal of Animal Ecology 65: 242-248. https://doi.org/10.2307/5727 
13. TIMM R.M. (1983). Fahrenholz's rule and resource tracking: a study of host-parasite coevolution. In: NiteCKi M.H. (ed.) Coevolution: 225-265. University Chicago Press, Chicago.

14. VAlim M.P. \& KUABARA K.M.D. (2015). The feather louse genus Mulcticola Clay et Meinertzhagen, 1938 (Phthiraptera: Philopteridae) from Brazil, with descriptions of five new species and catalogue for species described in the genus. Folia Parasitologica 62: 036.

https://doi.org/10.14411/fp.2015.036

15. KuABARA K.M.D. \& VAlim M.P. (2017). New records of chewing lice (Insecta, Phthiraptera) from Brazilian birds (Aves) collected by Helmut Sick (1910-1991). Revista Brasileira de Entomologia 61 (2): 146-161. https://doi.org/10.1016/j.rbe.2016.12.006

16. Hellenthal R.A., Price R.D. \& Palma R.L. (2014). Chewing Lice of Belgium. 59 pp. Available from https://www.yumpu.com/it/bch-cbd.naturalsciences.be [accessed 17 April 2018].

17. BAKER J.R. (1956). Studies on Trypanosoma avium Danilewsky 1885. 2. Transmission by Ornithomyia avicularia L. Parasitology 46: 321-344.

18. SpRINGETT B.P. (1968). Aspects of the relationship between burying beetles, Necrophorus spp. and the mite, Poecilochirus necrophori Vitz. Journal of Animal Ecology 37: 417-424. https://doi.org/10.2307/2957

19. WALtheR B.A. \& CLAYTON D.H. (1997). Dust-ruffling: a simple method for quantifying ectoparasite loads of live birds. Journal of Field Ornithology 68: 509-518.

20. FOWLER J.A. (1984). A safer anaesthetic for delousing live birds. Ringer's Bulletin 6: 69.

21. GALlowaY T.D. \& LAMB R.J. (2015). Abundance and stability of populations of a chewing louse, Mulcticola macrocephalus (Phthiraptera: Philopteridae), on common nighthawks, Chordeiles minor (Caprimulgiformes: Caprimulgidae) in Manitoba, Canada. The Canadian Entomologist 147: 723731. https://doi.org/10.4039/tce.2014.85

22. Clayton D.H. \& Walther B.A. (2001). Influence of host ecology and morphology on the diversity of Neotropical bird lice. Oikos 94: 455-467. https://doi.org/10.1034/j.1600-0706.2001.940308.x

23. DuRKIN E.S., LuONG L.T. \& BIRD J. (2015). Mechanisms underlying parasite infection: influence of host body mass and age on chewing louse distribution among brown-headed cowbirds. Parasitology Research 114: 4169-4174. https://doi.org/10.1007/s00436-015-4648-z

24. WhitEMAN N.K. \& PARKER P.G. (2004). Effects of host sociality on ectoparasite population biology. Journal of Parasitology 90: 939-947. https://doi.org/10.1645/GE-310R

25. Eveleigh E.S. \& Threlfall W. (1976). Population dynamics of lice (Mallophaga) on auks (Alcidae) from Newfoundland. Canadian Journal of Zoology 54: 1694-1711. https://doi.org/10.1139/z76-197

26. LeE P.L. \& Clayton D.H. (1995). Population biology in swift (Apus apus) ectoparasites in relation to host reproductive success. Ecological Entomology 20: 43-50. https://doi.org/10.1111/j.1365-2311.1995.tb00427.x

27. ŠtefKa J., Hoeck P.E.A., KelLeR L.F. \& SMith V.S. (2011). A hitchhikers guide to the Galápagos: co-phylogeography of Galápagos mockingbirds and their parasites. BMC Evolutionary Biology 11: 284. https://doi.org/10.1186/1471-2148-11-284

Manuscript received: 24 July 2017

Manuscript accepted: 31 January 2018

Published on: 17 April 2018

Branch editor: Marcel Eens 